\title{
Detection of the phycotoxin pectenotoxin-2 in waters around King George Island, Antarctica
}

\author{
Bernd Krock ${ }^{1}$ - Irene R. Schloss ${ }^{2,3,4} \cdot$ Nicole Trefault $^{5}$ - Urban Tillmann ${ }^{1} \cdot$ Marcelo Hernando $^{6}$ - Dolores Deregibus ${ }^{2,8}$. \\ Julieta Antoni ${ }^{7,8} \cdot$ Gastón O. Almandoz ${ }^{7,8} \cdot$ Mona Hoppenrath $^{9}$
}

Received: 29 April 2019 / Revised: 29 January 2020 / Accepted: 8 February 2020

(c) The Author(s) 2020, corrected publication 2021

\begin{abstract}
In order to set a base line for the observation of planktonic community changes due to global change, protistan plankton sampling in combination with phycotoxin measurements and solid phase adsorption toxin tracking (SPATT) was performed in two bays of King George Island (KGI) in January 2013 and 2014. In addition, SPATT sampling was performed in Potter Cove during a one-year period from January 2014 until January 2015. Known toxigenic taxa were not firmly identified in plankton samples but there was microscopical evidence for background level presence of Dinophysis spp. in the area. This was consistent with environmental conditions during the sampling periods, especially strong mixing of the water column and low water temperatures that do not favor dinoflagellate proliferations. Due to the lack of significant abundance of thecate toxigenic dinoflagellate species in microplankton samples, no phycotoxins were found in net tow samples. In contrast, SPATT sampling revealed the presence of dissolved pectenotoxin-2 (PTX-2) and its hydrolyzed form PTX-2 seco acid in both bays and during the entire one-year sampling period. The presence of dissolved PTX in coastal waters of KGI is strong new evidence for the presence of PTX-producing species, i.e., dinoflagellates of the genus Dinophysis in the area. The presence of phycotoxins and their respective producers, even at the low background concentrations found in this study, may be the seed of possible proliferations of these species under changing environmental conditions. Furthermore, phycotoxins can be used as chemotaxonomic markers for a very specific group of plankton thus allowing to track the presence of this group over time.
\end{abstract}

Keywords Protistan plankton community $\cdot$ Dinoflagellates $\cdot$ Phycotoxin $\cdot$ Liquid chromatography-tandem mass spectrometry $($ LC-MS/MS) $\cdot$ Solid phase adsorption toxins tracking $($ SPATT) $\cdot$ Harmful algae bloom (HAB)

Bernd Krock

bernd.krock@awi.de

$1 \quad$ Alfred Wegener Institut-Helmholtz Zentrum für Polarund Meeresforschung (AWI), Am Handelshafen 12, 27570 Bremerhaven, Germany

2 Instituto Antártico Argentino, 25 de mayo 1143, B1650KNA San Martín, Buenos Aires, Argentina

3 Centro Austral de Investigaciones Científicas (CADIC-CONICET), Bernardo Houssay 200, V9410CAB Ushuaia, Tierra del Fuego, Argentina

4 Universidad Nacional de Tierra del Fuego, Fuegia Basket 251, V9410CAB Ushuaia, Argentina

5 Centro GEMA - Genómica, Ecología y Medio Ambiente, Facultad de Ciencias, Universidad Mayor, Camino La Pirámide 5750, Huechuraba, Santiago, Chile
6 Departamento de Radiobiología, Comisión Nacional de Energía Atómica, Av. General Paz 1499, B1650KNA San Martín, Buenos Aires, Argentina

7 División Ficología, Facultad de Ciencias Naturales y Museo, Universidad Nacional de La Plata, Paseo del Bosque s/n, B1900FWA La Plata, Argentina

8 Consejo Nacional de Investigaciones Científicas y Técnicas (CONICET), Godoy Cruz 2290, C1425FQB Ciudad Autónoma de Buenos Aires, Argentina

9 Senckenberg am Meer, Deutsches Zentrum für Marine Biodiversitätsforschung (DZMB), Südstrand 44, 26382 Wilhelmshaven, Germany 


\section{Introduction}

During the second half of the twentieth century, the Western Antarctic Peninsula was one of the most affected areas by Global Change, although some cooling trend was evident after 1998 (Turner et al. 2016). These observations can be better described as a delayed warming shaped by the Southern Ocean's meridional overturning circulation and reflect the natural variability superimposed to the long-term warming trend (Armour et al. 2016). However, the overall warming of the sea at the West Antarctic Peninsula remains statistically significant (Henley et al. 2019). Increasing temperatures significantly affect sea and glacier ice dynamics, resulting in increased water column stratification when melting occurs, in turn affecting mixing regimes, nutrient supply, and light availability for Antarctic phytoplankton (Vernet et al. 2008; Schloss et al. 2012; Ducklow et al. 2013).

Surface salinity decrease has a significant impact on coastal Antarctic phytoplankton community composition (Hernando et al. 2015). The aforementioned study evidenced a decrease in the relative abundance of large centric diatoms and an increase in small pennate diatoms such as Fragilariopsis cylindrus and F. nana after 7 days of exposure to low salinity conditions. In addition, increased temperature and meltwater extend thermal stratification and strengthen the salinity gradient, which may explain some of the changes in phytoplankton dominance (Moline et al. 2004; Mendes et al. 2013). For temperate regions, increased stratification of the water column has been proposed to enhance dinoflagellate growth in coastal assemblages (Margalef 1978; Glibert 2016) and temperature, along with light, influences the germination of dinoflagellate cysts (Anderson et al. 2005). As a consequence, warming trends might result in Harmful Algae Bloom (HAB) seed populations appearing in Antarctic surface coastal waters, reflecting the onset of permissive temperatures for germination (Kremp and Anderson 2000) and increased germination rates favored at higher temperatures (Anderson et al. 2005).

Global Change may lead to a range extension of temperate and subpolar phytoplankton species to Polar Regions (Hallegraeff 2010). Coastal Antarctic waters are relatively isolated from the rest of the world oceans by the Antarctic Circumpolar Current (ACC), and thus an endemic phytoplankton community can be expected in Antarctic waters (Medlin et al. 2000). However, non-endogenous species, including potentially toxic species, may enter Antarctica through ship traffic (Bailey 2015). Successful "invasions" of new HAB species will depend fundamentally on their ability to compete with the local species assemblages, especially under Global Change induced changes in environmental conditions. Antarctic spring blooms are typically dominated by diatoms (Kim et al. 2018), but almost nothing is known about the occurrence of harmful dinoflagellate species and their associated phycotoxins in Antarctic waters.

The aim of this work was to investigate the presence of potentially toxigenic microalgae and their phycotoxins in coastal waters of King George Island or Isla 25 de Mayo, hereafter KGI, South Shetland Islands, Antarctica, in an effort to detect changes in coastal Antarctic environments due to Global Change. As HAB species levels in Antarctic waters were expected to be very low, integrative sampling of lipophilic phycotoxins was applied in order to be able to detect minute amounts of these molecules. In addition, it was aimed to assess the seasonal distribution of phycotoxins by implementing a phycotoxin survey during an entire year.

\section{Material and methods}

\section{Study areas}

Different datasets were obtained from Fildes Bay (62.2031 ${ }^{\circ}$ $\left.\mathrm{S}, 58.9208^{\circ} \mathrm{W}\right)$ and Potter Cove $\left(62.2373^{\circ} \mathrm{S}, 58.7009^{\circ} \mathrm{W}\right)$, KGI, South Shetland Islands, Western Antarctic Peninsula, during January 2013 (Fildes Bay) and January 2014 (Potter Cove) (Fig. 1). In addition, a year-round measurement of dissolved phycotoxins and CTD parameters was obtained for Potter Cove (2014-2015) that was complemented with a long-term plankton analysis.

\section{Fildes bay}

\section{Field sampling}

Salinity, fluorescence, oxygen and temperature data were obtained at Fildes Bay (FB) station $\left(62.2031^{\circ} \mathrm{S}, 58.9708^{\circ} \mathrm{W}\right.$; Fig. 1) using a SBE 911 plus (Sea-Bird Scientific, Oregon, USA) CTD profiler $(11,12,14,17,18,21,22,23$ and 25 January 2013). The CTD casts were processed and validated with the SBE data processing software version 7.23.2. Additionally, on each sampling day, seawater samples were collected at FB station using 5-L Niskin bottles. Samples were taken near the surface $(5 \mathrm{~m})$ and at a depth corresponding to $10 \%$ of the surface photosynthetically active radiation (PAR) (app. $25 \mathrm{~m}$ ). Samples were pre-filtered on board through a $150-\mu \mathrm{m}$ mesh to remove zooplankton and large particles. Samples were stored in acid-washed plastic carboys and kept in darkness until further processing. Once at the laboratory ( $<2 \mathrm{~h}$ later), subsamples for microscopy and molecular analyses were taken.

In addition, the upper $20 \mathrm{~m}$ of the water column were sampled by six vertical net tows $(40 \mathrm{~cm}$ diameter, $20-\mu \mathrm{m}$ 


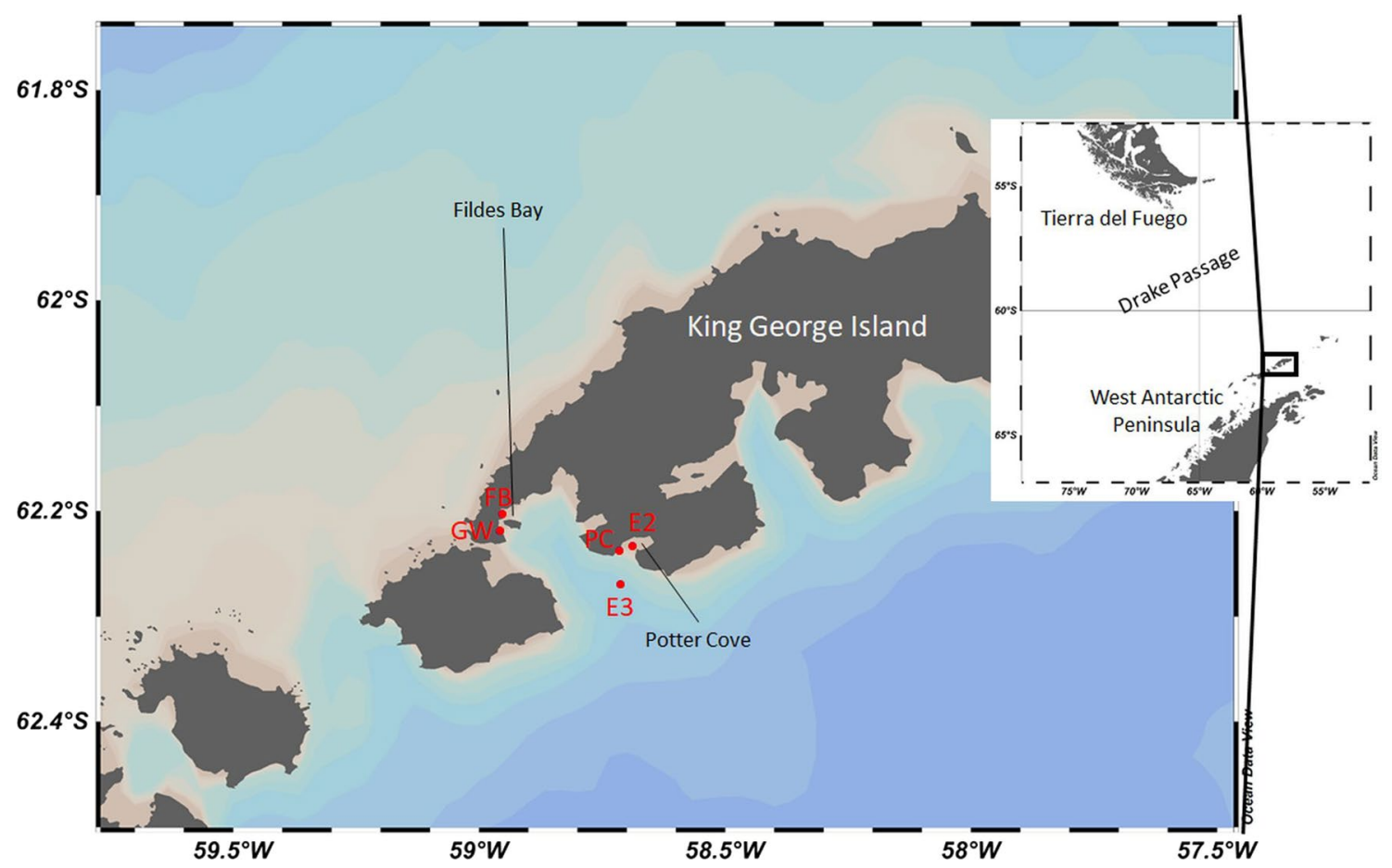

Fig. 1 Geographic locations of SPATT deployments in Fildes Bay (FB), Great Wall station (GW), Potter Cove (PC) and E3 during the two field seasons 2013 and 2014-2015. Protistan plankton for the long-term series was partially sampled at E2

mesh size) and subsequently the combined microplankton concentrates were adjusted with filtered sea water to a final volume of $500 \mathrm{~mL}$ and the rest was size fractionated over meshes of $150 \mu \mathrm{m}, 60 \mu \mathrm{m}$ und $20 \mu \mathrm{m}$ with a $7553-75$ peristaltic pump (Cole-Palmer, Vernon Hills, IL, USA) in order be able to attribute phycotoxins to planktonic groups. Plankton of each mesh were rinsed with $0.2-\mu \mathrm{m}$ filtered seawater into 50-mL centrifugation tubes (Sarstedt, Nümbrecht, Germany) and adjusted to $45 \mathrm{~mL}$. Each fraction was split into three $15-\mathrm{mL}$ aliquots and each aliquot was centrifuged at $8600 \times g$ for 20 min (Sigma 2-16 PK, Sartorius, Göttingen, Germany). Supernatants were removed and pellets re-suspended in ca. $1 \mathrm{~mL} 0.2-\mu \mathrm{m}$ filtered seawater, transferred to $2 \mathrm{~mL}$ centrifugation tubes and centrifuged again for $20 \mathrm{~min}$ at $21,460 \times g$ and $4{ }^{\circ} \mathrm{C}($ Sigma $2-16 \mathrm{PK})$. Supernatants were removed and two pellets of each station and size fraction (hydrophilic and lipophilic phycotoxins) were frozen at $-20{ }^{\circ} \mathrm{C}$ for phycotoxin analysis.

\section{Solid phase adsorption toxin tracking sampling}

SPATT (MacKenzie et al. 2004) bags $(5 \times 5 \mathrm{~cm})$ were hand sewed of 50- $\mu \mathrm{m}$ mesh gauze and filled with $1 \mathrm{~g}$ Diaion HP20 (Sigma, Deisenhofen, Germany). Filled SPATT bags were conditioned by immersion into methanol and stirring overnight. Conditioned SPATTs were washed with deionized water, individually placed moist into a zip-lock bag and kept
Table 1 SPATT deployment times and locations in January 2013

\begin{tabular}{lllllll}
\hline & \multicolumn{2}{l}{ Deployment } & & & \\
SPATT \# & From & To & $\begin{array}{l}\text { Exposure } \\
\text { time (d) }\end{array}$ & Latitude ${ }^{\circ} \mathrm{S}$ & Longitude ${ }^{\circ} \mathrm{W}$ & Station \\
\hline 1 & 14.1 .2013 & 18.1 .2013 & 4 & 62.2024 & 58.9538 & $\mathrm{FB}$ \\
2 & 16.1 .2013 & 21.1 .2013 & 5 & 62.2186 & 58.9588 & $\mathrm{GW}$ \\
3 & 22.1 .2013 & 29.1 .2013 & 7 & 62.2370 & 58.7153 & $\mathrm{PC}$ \\
4 & 18.1 .2013 & 23.1 .2013 & 5 & 62.2024 & 58.9538 & $\mathrm{FB}$ \\
5 & 21.1 .2013 & 26.1 .2013 & $5^{*}$ & 62.2186 & 58.9588 & $\mathrm{GW}$ \\
\hline
\end{tabular}

$F B$ fildes Bay, GW Great Wall station, $P C$ Potter Cove

Asterisk (*) denotes SPATT that was retrieved dry and exact exposure time cannot be determined 
at $4{ }^{\circ} \mathrm{C}$ until use. SPATTs were placed at different localities in KGI for approximately five days (Fig. 1, Table 1).

\section{Protistan plankton analysis by microscopy}

Aliquots of $1 \mathrm{~mL}$ from the Niskin bottles without fixation were screened under a CX21FS light microscope (Olympus, Tokyo, Japan) with $40 \mathrm{x}$ magnification. In addition, from each sampling day at Fildes Bay (2013), 50-mL seawater samples from the Niskin bottles were fixed with formalin (1\%) and stored at room temperature in the dark, until further analyses. For a non-quantitative analysis (search for Dinophysis cells) the whole sample volume was partitioned in several small plastic Petri dishes (5.5 $\mathrm{cm}$ in diameter) and after cell settlement completely scanned with a Leica DMIL inverted microscope (Leica Microsystems, Wetzlar, Germany) at $200 \times$ and $400 \times$ magnification.

\section{Molecular analysis}

One seawater sample (4.5 L) taken on 18 Jan 2013 was size fractionated using a 7553-75 peristaltic pump (Cole-Palmer) by sequential filtration using $47-\mathrm{mm}$ diameter Swinnex filter holder (Millipore), and $60-\mu \mathrm{m}, 20-\mu \mathrm{m}$ (Nylon, Millipore, Burlington, MA, USA), 12- $\mu \mathrm{m}, 3-\mu \mathrm{m}$ and $0.2-\mu \mathrm{m}$ (Polycarbonate, Millipore) pore size filters. Filters were stored in 2 -mL cryovials at $-80{ }^{\circ} \mathrm{C}$ until analysis. DNA extraction, quantitation, amplicon sequencing by Next Generation Sequencing (NGS) and bioinformatic analyses were performed according to Rodríguez-Marconi et al. (2015). Briefly, DNA was extracted following a general hexadecyltrimethyl-ammonium bromide (CTAB) and phenol-chloroform method. Tag sequencing was performed on a Illumina MiSeq platform following Caporaso et al. (2011) protocol and using 1391f and EukBr primers (Amaral-Zettler et al. 2009) for amplification of the hypervariable region V9 of the 18S rRNA gene. Sequences were analyzed using Mothur software (Schloss et al. 2009). Raw sequence data were deposited in SRA under BioProject number PRJNA287634, corresponding to SW samples, as indicated in RodríguezMarconi et al. (2015).

\section{Potter Cove}

\section{Plankton sampling}

A SBE CTD (Sea-Bird Scientific, Oregon, USA) was used to record seawater temperature and conductivity (transformed in salinity) profiles from the surface down to around $30 \mathrm{~m}$. Density was estimated, and the Brunt-Väisälä frequency $\left(\mathrm{N}^{2}\right)$ was calculated as in Schloss et al. (2014). Additionally, the upper $20 \mathrm{~m}$ of the water column were sampled by six vertical net tows ( $40 \mathrm{~cm}$ diameter, $20-\mu \mathrm{m}$ mesh size) and subsequently the combined plankton concentrates were taken to $1000 \mathrm{~mL}$ with $0.2-\mu \mathrm{m}$ filtered seawater. $50 \mathrm{~mL}$ were taken for microscopy (see below) and the rest was size fractionated over meshes of $200 \mu \mathrm{m}, 50 \mu \mathrm{m}$ und $20 \mu \mathrm{m}$ by gravity filtration. Plankton of each mesh were rinsed with $0.2-\mu \mathrm{m}$ filtered seawater into 50-mL centrifugation tubes (Sarstedt, Nümbrecht, Germany) and adjusted to $45 \mathrm{~mL}$. Each fraction was split into three $15-\mathrm{mL}$ aliquots and each aliquot was centrifuged at $4000 \times g$ for 15 min (model 5403, rotor 16 A4-44, Eppendorf, Hamburg, Germany). Supernatants were removed and pellets re-suspended in ca. $1 \mathrm{~mL} 0.2-\mu \mathrm{m}$ filtered seawater, transferred to $2-\mathrm{mL}$ centrifugation tubes and centrifuged again at $4000 \times g$ for $15 \mathrm{~min}$. Supernatants were removed and two pellets of each station for phycotoxin analysis (hydrophilic and lipophilic phycotoxins) were frozen at $-20^{\circ} \mathrm{C}$ until analysis.

Additionally, discrete water samples were collected at five depths (i.e., 0, 5, 10, 20 and $30 \mathrm{~m}$ ) with $4.7 \mathrm{~L}$ Niskin bottles.

\section{Solid phase adsorption toxin tracking sampling}

SPATT bags consisted of $50 \times 150$-mm filter bags (Carbis Filtration, Stockton-On-Tees, Great Britain), were filled with $10 \mathrm{~g}$ Diaion HP20 (Sigma, Deisenhofen, Germany) and sealed with Holdon Midi Clips (Thomann, Burgebrach, Germany). Filled SPATT bags were conditioned by immersion into methanol and stirring overnight. Conditioned SPATTs were washed with deionized water, individually placed moist into a zip-lock bag and kept at $4{ }^{\circ} \mathrm{C}$ until use. SPATTs were deployed at the mooring at the permanent sampling station E2 in Potter Cove, KGI $\left(62.2328^{\circ} \mathrm{S}, 58.6886^{\circ} \mathrm{W}\right.$, Fig. 1) during the one-year period from February 2014 to January 2015. SPATTs were deployed for approximately one month

Table 2 SPATT deployment times and locations from January 2014 to February 2015 at sampling station E2 $\left(62.2328^{\circ} \mathrm{S}, 58.6886^{\circ} \mathrm{W}\right.$, $\left.62.2693^{\circ} \mathrm{S}, 58.7136^{\circ} \mathrm{W}\right)$

\begin{tabular}{llll}
\hline & \multicolumn{2}{l}{ Deployment } & \\
\cline { 2 - 3 } SPATT \# & From & To & $\begin{array}{l}\text { Expo- } \\
\text { sure } \\
\text { time [d] }\end{array}$ \\
\hline 2 & 18.02 .2014 & 18.03 .2014 & 28 \\
3 & 18.03 .2014 & 21.04 .2014 & 34 \\
4 & 21.04 .2014 & 21.05 .2014 & 30 \\
5 & 25.05 .2014 & s.1. & - \\
6 & 07.06 .2014 & 18.07 .2014 & 41 \\
7 & 18.07 .2014 & 10.09 .2014 & 53 \\
8 & 10.09 .2014 & 16.10 .2014 & 35 \\
9 & 16.10 .2014 & 21.11 .2014 & 36 \\
10 & 21.11 .2014 & 20.12 .2014 & 29 \\
11 & 20.12 .2014 & 18.02 .2015 & 40 \\
\hline
\end{tabular}

s.l. sample lost 
of exposure time (between 29 and 53 days) depending on accessibility of the sampling site due to weather conditions and ice coverage (Table 2, Fig. S2).

\section{Protistan plankton analysis by microscopy}

Microplankton net samples $>20 \mu \mathrm{m}$ and bottle samples were used for protistan plankton microscopical observation and documentation. For bottle samples, 1-L sample was gently concentrated by gravity filtration using a $3-\mu \mathrm{m}$ polycarbonate filter (47 mm diameter, Whatman, Chicago, IL, USA), and examined using an Diavert inverted microscope (Leica Microsystems, Wetzlar, Germany). Micrographs were taken with a MicrOculareyepiece-camera (Bresser, Rhede, Germany).

\section{Long-term summer plankton composition}

Data presented here are part of the sampling conducted close to the Argentinean Carlini Station (formerly called Jubany) as part of a long-term monitoring program. Water was collected at two sites, E2 $\left(62.2328^{\circ} \mathrm{S}, 58.6886^{\circ} \mathrm{W}\right)$ and E3 $\left(62.2693^{\circ} \mathrm{S}, 58.7136^{\circ} \mathrm{W}\right)$, with 4.7 -L Niskin bottles during the Austral summers 2010, 2011-2012, 2014-2016 (Table S1). Aliquots of $150 \mathrm{~mL}$ were fixed with $4 \%$ acetic Lugol's solution and kept in dark conditions at room temperature until analysis. For quantitative estimation of plankton assemblage composition, cells were enumerated with a phase contrast Leica DMIL LED inverted microscope (Leica Microsystems, Wetzlar, Germany) according to the procedures described by Utermöhl (1958). Subsamples of $50 \mathrm{~mL}$ were settled for $24 \mathrm{~h}$ in a composite sedimentation chamber. At least 100 cells of the dominant taxa were counted in one or more strips of the chamber or random fields at 250 $\mathrm{x}$ or $400 \mathrm{x}$, depending on their concentration and size. To count large and sparse species, the whole surface of the chamber was scanned at a magnification of $\times 100$, with a detection limit of 20 cells $\mathrm{L}^{-1}$. Small unidentified specimens other than diatoms, dinoflagellates (phototrophic- and heterotrophic taxa) cryptophytes, prasinophytes and silicoflagellates were included in a single group as 'flagellates' and classified according to their size.

\section{Ice cover data}

The annual number of days with fast ice was obtained by daily photographic observations of Potter Cove from January 2014 to March 2015 (Gómez Izquierdo et al. 2014, 2015). With these photographic images it was registered whether the cove was frozen or not.

\section{Phycotoxin extraction from passive samplers}

SPATT bags were rinsed with deionized water, placed on tissue paper for removal of excess water and dried in an oven for one hour at $50{ }^{\circ} \mathrm{C}$. Dry SPATT bags were opened and the resin was transferred into $50-\mathrm{mL}$ centrifugation tubes. $25 \mathrm{~mL}$ methanol was added and left over night. The next day each resin-methanol mixture was poured into a glass chromatography column $(270 \mathrm{~mm}$ length, $13 \mathrm{~mm}$ internal diameter, filled with $20 \mathrm{~mm}$ glass wadding and $10 \mathrm{~mm}$ quartz sand). Additional $15 \mathrm{~mL}$ methanol were used to rinse the centrifugation tube and added to the column. Methanol was eluted dropwise from the column until the supernatant reached the top of the filling and $25 \mathrm{~mL}$ methanol were added to the column and subsequently eluted. The eluate was reduced in a rotary evaporator to approximately $0.5 \mathrm{~mL}$ and then taken to $1 \mathrm{~mL}$ with methanol.

\section{Phycotoxin measurements}

Hydrophilic phycotoxins were measured by ion pair chromatography with fluorescence detection and post-column derivatization as described in Krock et al. (2007). Lipophilic phycotoxins and domoic acid (DA) were measured by liquid chromatography-tandem mass spectrometry in the selected reaction monitoring (SRM) mode as described by Krock et al. (2008).

\section{Results}

\section{Environmental conditions in the study areas}

In Fildes Bay, sea surface temperature increased during the studied period (Fig. 2), starting around 16 January, with a peak registered on 23 January $\left(1.25^{\circ} \mathrm{C}\right)$. The first increase was accompanied by a slight decrease in surface salinity (from 34.1 to 34.05 ), and contributed to the observed weak density stratification. The presence of a colder, saltier and denser water mass was evident at depth $>30 \mathrm{~m}$ probably entering from Maxwell Bay (see Höfer et al. 2019). No evident water mixing event was observed during the study period in this enclosed bay. In Potter Cove sea surface water temperature followed the seasonal cycle, although a cold-water mass was evident in February (Fig. 3a). Cold water characterized the fall and winter waters, and warming of the surface layers started in late October. Water column salinity (Fig. 3b) showed a homogeneous distribution in summer. A winter warming effect was evident in salinity, when a cold, fresh surface water mass entered the cove, probably as a result of air warming and glacial melting, which adds freshwater to the Cove. The effect of melting was also evident again 

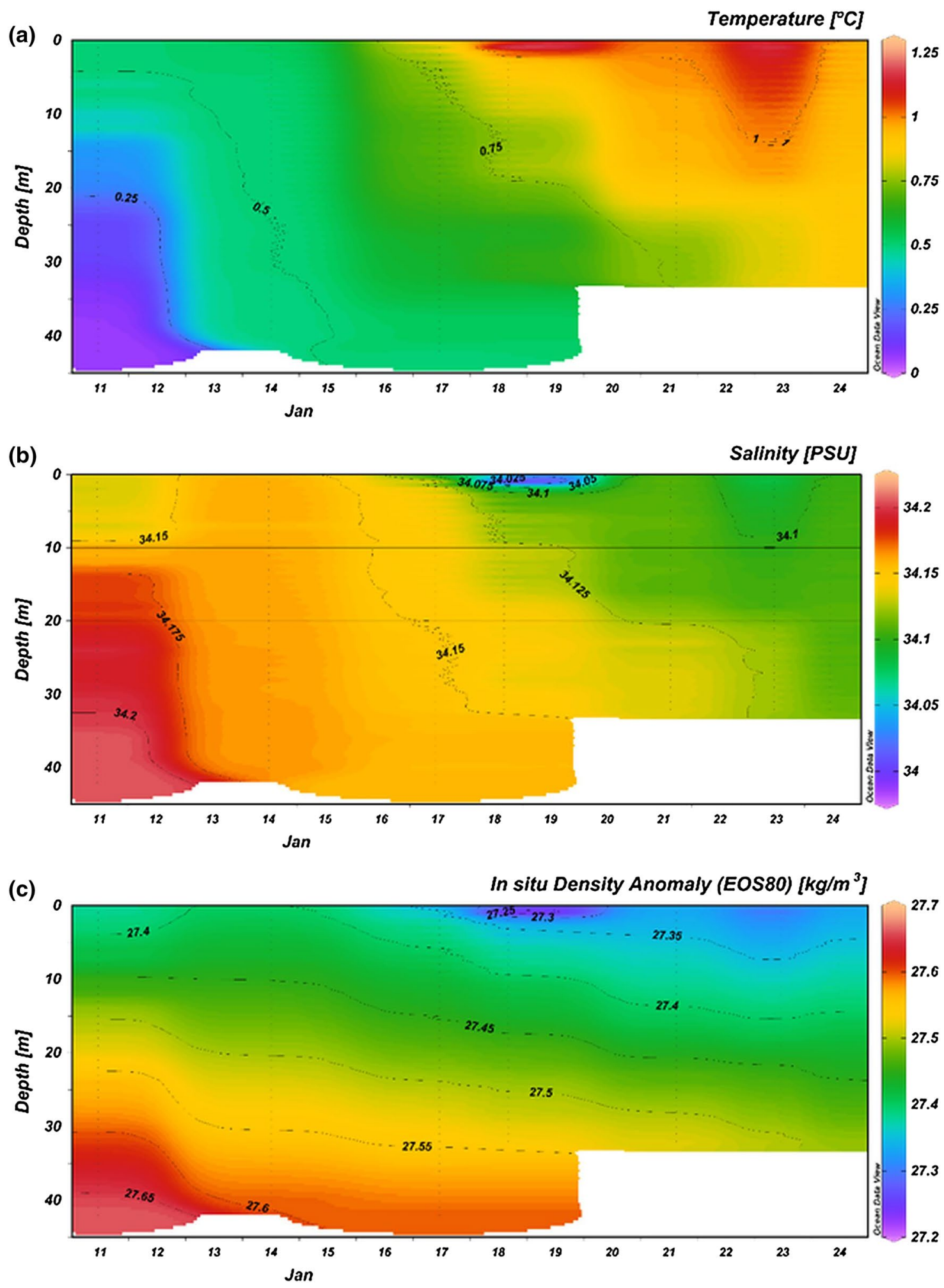

Fig. 2 a Sea water temperature, b salinity, and c density at Fildes Bay, KGI in January 2013

in the following summer season, in January, when low salinity and density surface waters were evident in the profiles. This was also apparent in the turbidity profiles at that time (Fig. 3c). The Brunt-Väisälä frequency, which estimates the static stability of the water column, was further considered as a measure of stratification strength 
Fig. 3 a Sea water temperature, b salinity, c turbidity at Potter Cove, KGI during the studied period. White areas correspond to periods for which no vertical CTD profiles are available

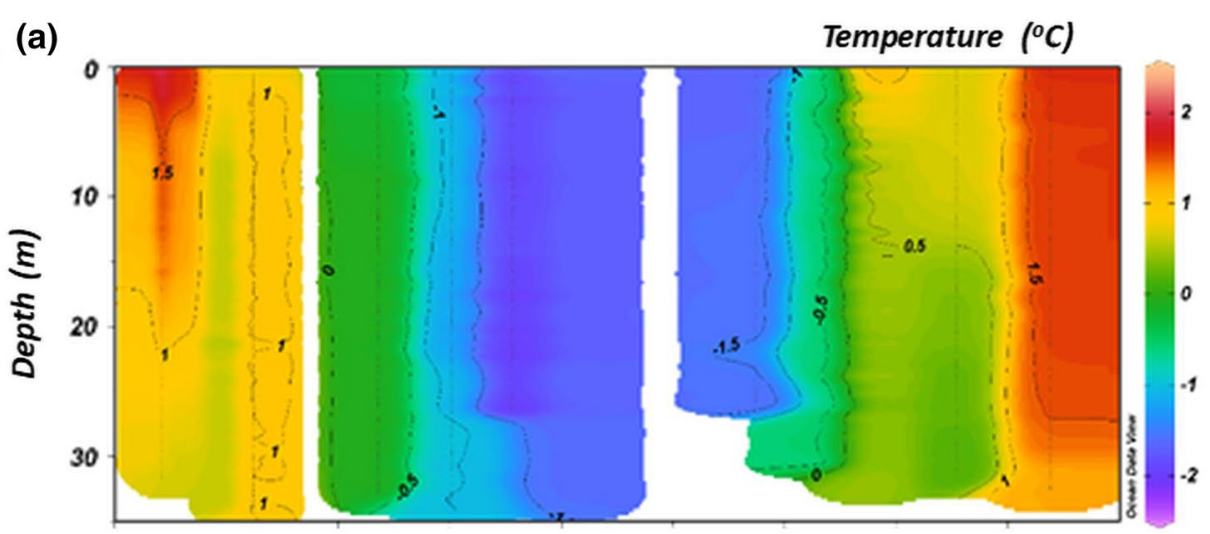

(b)

Salinity (PSU)
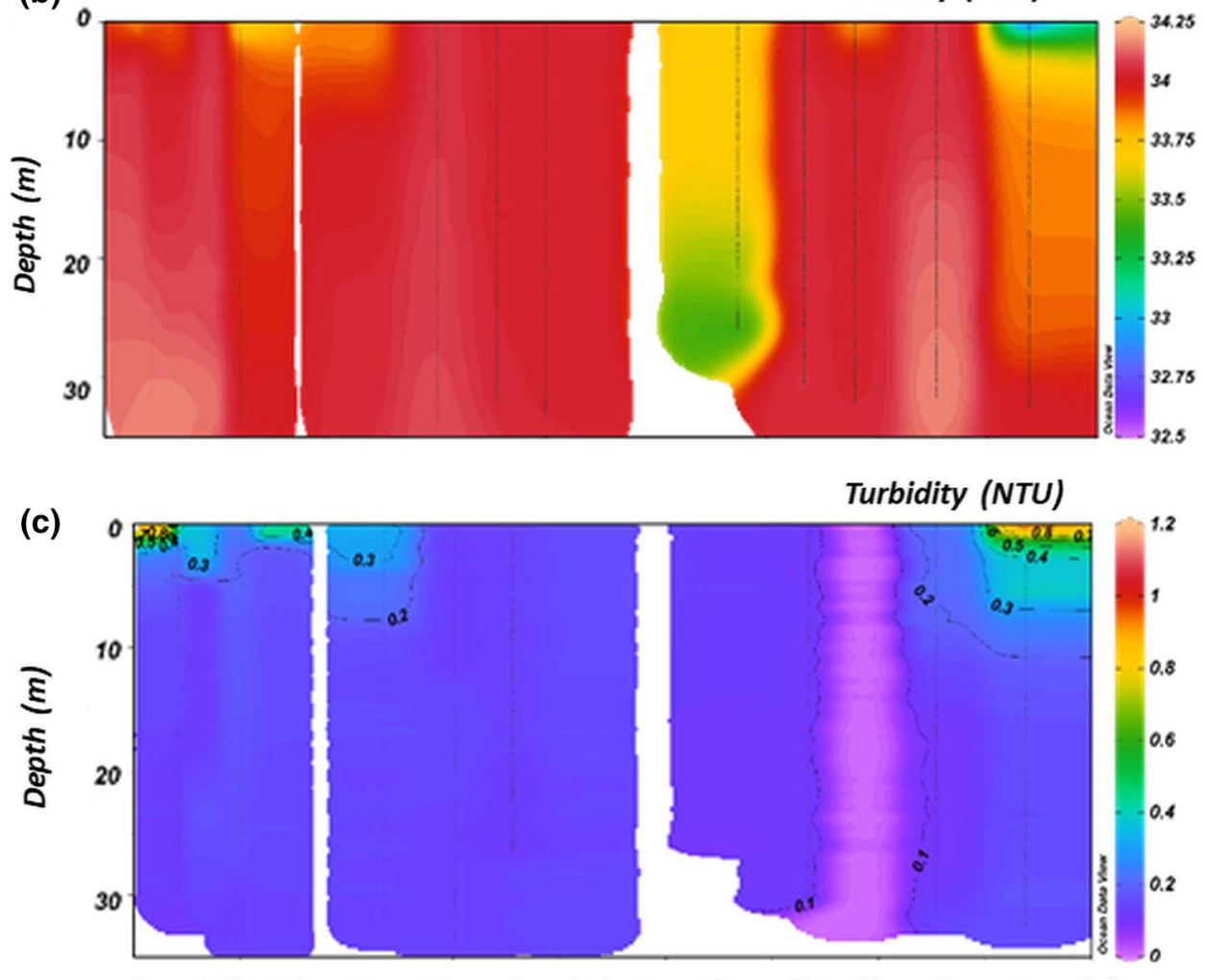

Jan Feb Mar Apr May Jun Jul Aug Sep Oct Nov Dec Jan Feb (as in Geyer et al 2008). Although values were somewhat lower in January and February 2014, there were in the same order of the climatic (1991-2016) average. In general, except for the winter months, the studied period presented a lower $\mathrm{N}^{2}$ value than the average (Fig. S1). Potter Cove was only frozen in total for less than two months (54 days) from June to October (Fig. S2). Moreover, between these months, there were several periods in which the cove was free of ice, and it was mainly frozen especially from August to mid-September.

\section{Phycotoxins}

Neither hydrophilic PSP toxins and domoic acid (DA) nor lipophilic phycotoxins (gymnodimines, spirolides, okadaic acid, dinophysistoxins, yessotoxin (YTX), pectenotoxins (PTX), azaspiracids) were detected in any of the nanoand microplankton concentrates taken during the summer expeditions in KGI in 2013 and 2014. The detection limits of these measurements ranged between 0.01 and $1 \mathrm{ng}$ per net tow depending on the sensitivity of each individual 
Table 3 Pectenotoxin-2 (PTX2) amounts [ng] per SPATT bag in Fildes Bay in January 2013

\begin{tabular}{lll}
\hline SPATT \# & $\begin{array}{l}\text { PTX-2 (ng } \\
\left.\text { SPATT }^{-1}\right)\end{array}$ & Station \\
\hline 1 & 7.2 & FB \\
2 & 3.3 & GW \\
3 & 14.7 & PC \\
4 & 11.9 & FB \\
5 & nd & GW \\
\hline
\end{tabular}

For geographic locations of SPATT deployments see Fig. 1 nd not detected

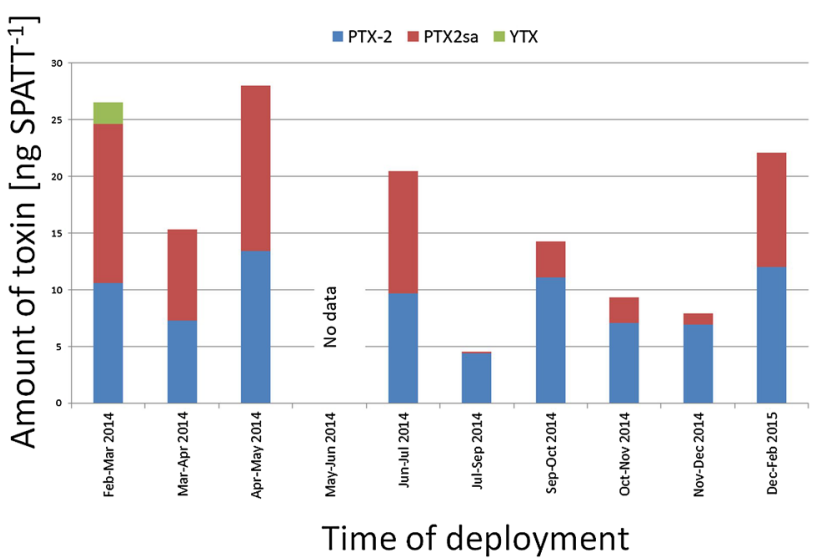

Fig. 4 Amounts [ng] of phycotoxins per SPATT bag detected in the time series from January 2014 to February 2015 at sampling station E2 in Potter Cove: pectenotoxin-2 (PTX-2, blue bars), pectenotoxins-2 seco acid (PTX-2sa, red bars) and yessotoxin (YTX, green bar)

phycotoxin (Table S2). On the other hand, pectenotoxin-2 (PTX-2) was detected on four out of five SPATT samplers during the austral summer expeditions in Fildes Bay and Potter Cove, KGI in January 2013. Amounts ranged from 3 to $15 \mathrm{ng}$ per SPATT bag and were present in almost all samplers (Table 3). This unexpected finding motivated the start of a continuous, long-time series of SPATT sampling for lipophilic phycotoxins in the area, which was performed in Potter Cove, KGI. This one-year long SPATT sampling from January 2014 to February 2015 revealed the presence of PTX-2 during the entire sampling period (Fig. 4), same as the sporadic SPATT samplings in Fildes Bay in the previous year (Table 3). All SPATT samplers contained PTX-2 in abundances from 4 to $14 \mathrm{ng}$ per SPATT bag.

In addition to PTX-2, also pectenotoxin-2 seco acid (PTX-2sa) was detected on all SPATT bags except for one corresponding to the winter period, i.e., July-September 2014. PTX-2sa levels were in the same range $(0.12-14.6 \mathrm{ng}$ SPATT $^{-1}$ ) as PTX-2, but tended to be lower in the winterspring period. In contrast to PTX-2sa, abundances of PTX-2 did not show any clear seasonal distribution patterns. The only other phycotoxin not related to PTX was YTX. YTX was only detected once at an abundance of $1.9 \mathrm{ng}$ SPATT ${ }^{-1}$ on a SPATT sampler deployed in the summer months, i.e., February-March 2014 (Fig. 4).

\section{Protistan plankton composition in Fildes Bay in 2013}

The detection of PTX-2 prompted the search for the toxinproducing organisms in these coastal waters. For this purpose, live plankton samples and fixed water samples obtained from Fildes Bay in January 2013 were inspected. Fixed water samples generally showed relatively low cell abundances. Microplankton communities in these samples were dominated by diatoms of the genera Thalassiosira and Corethron and contained to a lesser extent small Chaetoceros species, whereas dinoflagellates were not detected except for one occasion, where a Dinophysis cell was found by in situ microscopy (Fig. 5a). This cell contained plastids, was relatively large, laterally flattened with an epitheca hidden behind the upwards directed precingular list
Fig. 5 a Live Dinophysis norvegica cell photographed through the ocular of a microscope from a Niskin bottle sample taken in Fildes Bay in January 2013. b Light microscopy picture of a plankton concentrate from Potter Cove in January 2014 including an empty theca of Dinophysis
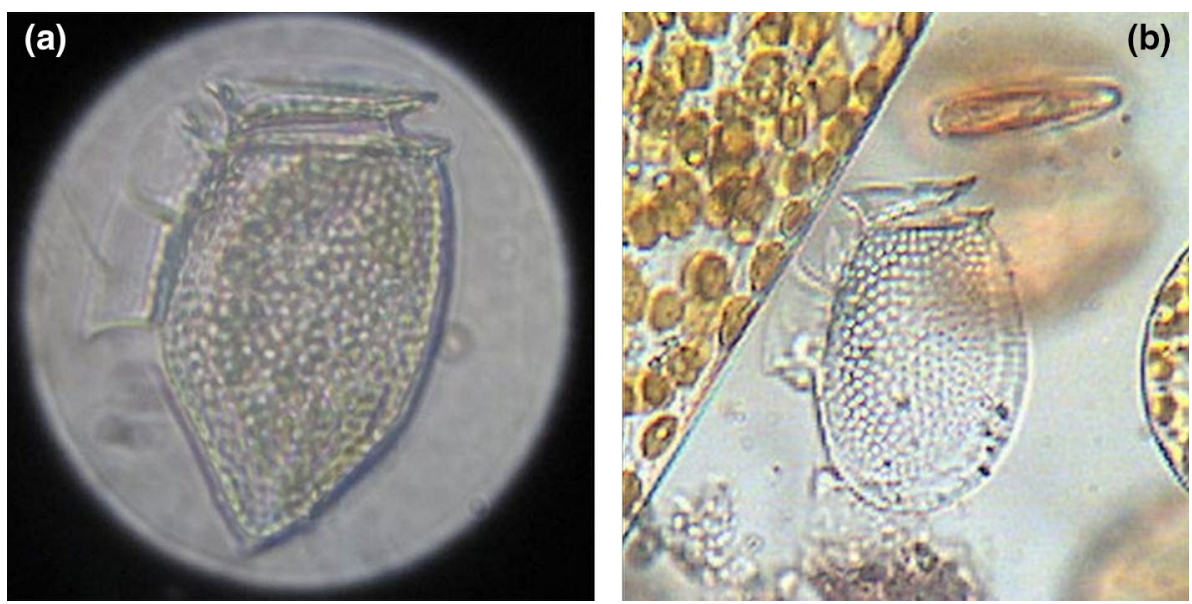
and the hypotheca being deepest about the middle level of its length, pointing posteriorly. The hypotheca was dorsally slightly convex and more straight ventrally below the sulcal list. The left sulcal list was longer than half the hypotheca length and the third rib was slightly pointing posteriorly. The theca had strong reticulate-foveate ornamentation (Fig. 5a). Based on these characters the cell was classified as Dinophysis norvegica.

\section{Molecular data from seawater samples of Fildes Bay in 2013}

After quality filtering and removal of undesired sequences (metazoan, chloroplast, mitochondria), a total of 1,599,680 sequences and 1600 OTUs were obtained. Stramenopiles captured most of the sequences $(1,321,926)$, followed by Alveolata $(126,768)$ and Hacrobia $(24,344)$ (Fig. S3). Unclassified sequences were $7.2 \%$ of the total sequences $(115,484)$. At higher taxonomical levels, Bacillariophyta was the most abundant group, with $88.5 \%$ of relative abundance. Dinophyceae corresponded to $8.3 \%$ of relative abundance. However, most of the sequences in this class were assigned to unclassified Dinophyceae, and sequences belonging to the genus Dinophysis nor even to the order Dinophysales could not be identified.

\section{Protistan plankton observations in Potter Cove in January 2014}

Microplankton communities during the sampling period were generally dominated by diatoms with high densities of various species of Thalassiosira and Corethron. Among the diatoms, cells of Pseudo-nitzschia were also regularly detected. Although relatively low in abundance, a high diversity of dinoflagellates was detected, but these almost exclusively belonged to the large group of athecate dinoflagellates, i.e., species without rigid plates, which could not be identified to the species level. Among thecate phototrophic dinoflagellates cells of a small Prorocentrum species were encountered quite regularly. One single empty theca of a species of Dinophysis resembling D. acuminata was encountered (Fig. 5b), but the extremely low abundance prevented a further species determination.

\section{Long-term summer protistan plankton composition in Potter Cove (2010-2016)}

Nano- and microplankton composition was characterized by the dominance of unidentified tiny flagellates $(<5 \mu \mathrm{m})$ and diatoms in all samples collected from 2010 to 2016, usually followed in relative abundance by cryptophytes and prasinophytes. Dinoflagellates were observed all along the sampling period, except in December 2013, with densities ranging from 80 to 40,000 cells $\mathrm{L}^{-1}$, but representing a small percentage (0.1-5.2\%) of total cells (Fig. 6). Dinoflagellate assemblages were mostly dominated by small $(<20 \mu \mathrm{m})$ naked gymnodinioid forms, which represented an average of $61 \%$ of total dinoflagellate abundance. Prorocentrum aff. balticum was another conspicuous and frequent taxon, representing up to $90 \%$ of total dinoflagellate abundance on 21 January 2014. Gyrodinium, Amphidinium and Protoperidinium species were also usually observed in lower densities. By contrast, cells of potentially toxic species of Dinophysis were not detected in any of the analyzed samples.

\section{Discussion}

\section{Environmental parameters}

Environmental conditions in coastal waters of KGI generally do not favor dinoflagellate blooms due to high water column mixing as inferred from the Brunt-Väisälä frequency (Fig. S1) and observed by in situ measurements (Fig. 2). The water column in Potter Cove usually is well mixed throughout the year, except for short periods during
Fig. 6 Density of dinoflagellates (cells $\mathrm{L}^{-1}$ ) and their relative contribution to total cell densities of protistan plankton based upon cell counts from Niskin bottle samples collected at Potter Cove during summer

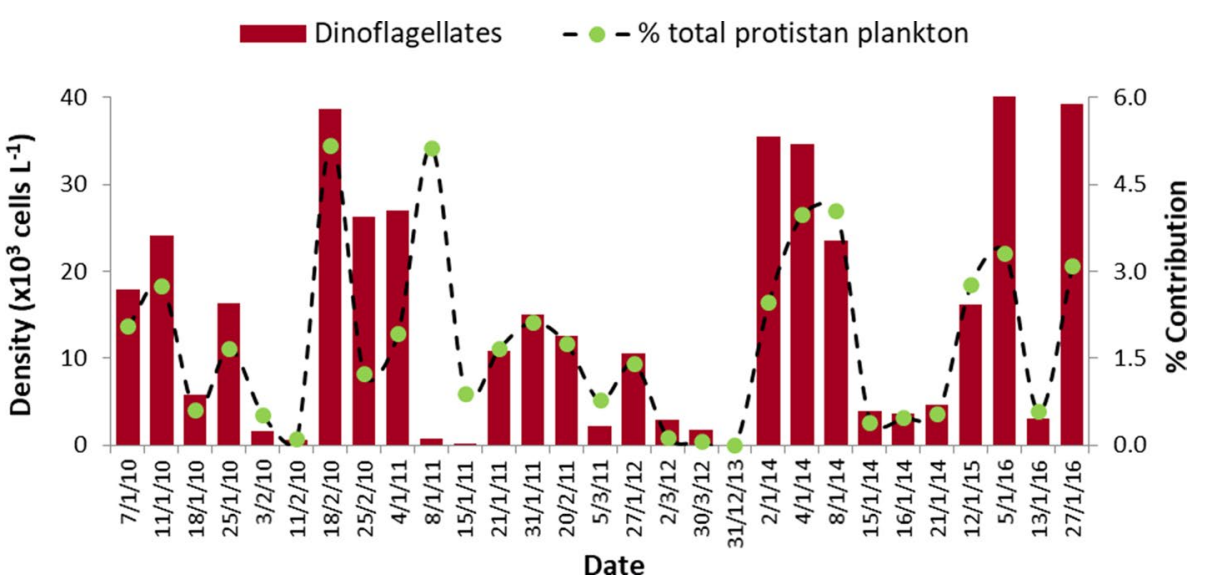


the summer months, when glacial ice melt generates a surface fresh water layer. Water temperature was quite uniform throughout the year ranging from maxima of $+2{ }^{\circ} \mathrm{C}$ in summer to minima of $-2{ }^{\circ} \mathrm{C}$ in winter (Fig. 2a). Previous inorganic nutrient data show that neither nitrate nor phosphate or silicate limit phytoplankton growth in this area (Schloss et al. 2014) further characterized by high concentrations of bioavailable iron (Henkel et al. 2018). The prevailing mixing and irradiance conditions do not normally favor phytoplankton bloom developments (e.g. Schloss et al. 2002). In particular, cold and well-mixed water bodies generally do not favor high abundances of dinoflagellates (Margalef 1978; Bresnan et al. 2009). Nevertheless, the occurrence of PTX was observed during the entire course of the year 2014 (Fig. 4), which is very strong evidence that there is a constant, albeit low production of these phycotoxins in the area. Interestingly, no seasonality of PTX amounts on SPATTs was observed, which is probably due to the integrative sampling mechanism of the SPATT technique that only adsorbs extracellular phycotoxins. Considering that polyketides are chemically stable compounds that partially survive harsh physical and biological conditions such as boiling and shellfish metabolism, the presence of PTX on SPATTs throughout a 12 month period can be explained by a long persistence of this phycotoxin in the Antarctic cold-water system and is only an indirect proof of the presence of PTX-producing species and not directly linked to their spatial and temporal abundances. Other seasonal factors, such as the availability of the ciliate Mesodinium rubrum, the obligate prey of most, if not all Dinophysis species (Reguera et al. 2012), or light availability, which in high latitudes is reduced especially in winter and under ice coverage (Campana et al. 2018), likely play a role for the seasonal dynamic of Dinophysis, although mixotrophy and photophysiology of Dinophysis indicate that these species seem to be rather well adapted to low light intensities (Hansen et al. 2016).

\section{Global change in Antarctica}

The West Antarctic Peninsula is one of the fastest warming areas of the world and for this reason, an expansion of non-indigenous temperate taxa, including toxigenic species, may occur with raising temperatures under a global change scenario (Wells et al. 2015). Nonetheless, to our knowledge, only two studies have detected potentially toxigenic dinoflagellate species in Antarctic waters reporting Alexandrium pacificum (reported as A. tamarense) (Ho et al. 2003), later revised as Group IV of the $A$. tamarense species complex (Ho et al. 2012), and finally renamed as A. pacificum (John et al. 2014) and several species of the genus Dinophysis (Kuzmenko 2004). In contrast, in the Arctic, a region also highly impacted by global change and with evidence of increasing temperatures, most toxigenic protists known from temperate regions have been found, including records of the associated phycotoxins (Okolodkov 2005; Vershinin et al. 2006; Gu et al. 2013; Harðardóttir et al. 2015; Lefebvre et al. 2016; Tillmann et al. 2016). This discrepancy could be due to the fact that Arctic waters are much more accessible and surrounded by inhabited land. For this reason, the high number of reports of toxigenic species and related phycotoxins in the Arctic may be a result of more rigorous monitoring programs and/or the introduction of toxigenic plankton by anthropogenic activities, an ongoing discussion also for other world regions (Mardones et al. 2017; Hallegraeff 2015). This lack of knowledge prompted the research of toxigenic species and phycotoxins in Antarctic waters.

The results presented here indicate very low abundance of Dinophysis (one cell of a PTX producer and one empty theca of an unidentified Dinophysis) and the unambiguous detection of dissolved PTX-2 and PTX-2sa in two different bays of KGI at a distance of app. $15 \mathrm{~km}$. This finding opens the question if the presence of toxigenic species in Antarctic coastal waters is a result of the range expansion of species from neighboring areas of the Southern Ocean, as the barrier of the Circumpolar Current could be more permeable than previously assumed (Fraser et al. 2017, 2018). Alternatively, recent introduction by human activities might be another explanation (Hughes and Ashton 2016, Hughes et al. 2019). A third possibility is that phycotoxin-producing species always have been present in Antarctic waters at background levels. However, independent of the origin of this potentially toxic plankton species, the risk of phycotoxin proliferation with raising temperatures and increasing water stratification due to higher meltwater input to coastal Antarctic areas exists. Accordingly, this possible change in the specific composition of plankton assemblages may be a potential problem for local fauna such as birds, whales or seals, especially in an area, where the entire food chain depends on marine primary production.

\section{Phycotoxin monitoring}

No phycotoxins were detected in plankton concentrates of as much as six pooled plankton net hauls at any station in the two subsequent austral summer expeditions of 2013 and 2014. Nevertheless, the presence of phycotoxins on SPATTs is an indication that there is an at least very low presence of toxigenic plankton species in coastal waters of KGI. On the other hand, plankton species are known to show patchy temporal and spatial distributions, which also could explain the absence of phycotoxins in the summer net tow samples and is consistent with only one coincidental observation of Dinophysis in a water sample from Fildes Bay. But this record prompted the employment of a more integrative phycotoxin passive sampling technique instead of punctual microplankton sampling at discrete locations 
and time points. SPATT originally has been developed in New Zealand for HAB monitoring to simulate phycotoxin accumulation in bivalves of shellfish harvesting areas by adsorption of lipophilic organic molecules dissolved in seawater (MacKenzie et al. 2004). SPATT samplers specifically adsorb large, lipophilic molecules dissolved in the water and thereby are ideal for the sampling of lipophilic phycotoxins with these properties. Due to this physical property, the low cost and easy applicability, its utilization rapidly has been expanded and successfully applied in several other countries (Shea et al. 2006; Lindahl et al. 2007; Fux et al. 2009; Li et al. 2010; García-Altares et al. 2014). Most phycotoxins are intracellular metabolites that are not actively excreted by healthy and well growing cells, but usually become part of the dissolved organic material (DOM) pool after cell death and lysis. Consequently, phycotoxin detection by SPATT samplers is an indirect proof of the presence of the producing species. Nevertheless, chemical stability of most marine biotoxins and their large molecular weight favor their selective adsorption to the adsorbent allowing for highly selective and sensitive detection of this class of biomolecules in seawater. Despite the above advantages, it has to be considered that SPATT sampling is not quantitative in a strict sense, even though phycotoxins can be precisely quantified on SPATT samplers. Adsorption is a reversible kinetic equilibrium process and adsorption kinetics for SPATT has not been investigated. Adsorption of phycotoxins also depends on several parameters, which cannot be controlled in the field, such as temperature, phycotoxin concentration, ratio of phycotoxins and other lipophilic components in the water, currents and other causes of water movement, bio-fouling, $\mathrm{pH}$, salinity, among others, make an extrapolation of phycotoxin contents of SPATT samplers to analyze concentration in the seawater impossible. However, it can be assumed that when most of the above mentioned parameters are relatively constant during the sampling period, at least relative comparisons among values derived from SPATT under similar conditions can be made in a semi-quantitative way and in any case give a qualitative picture of phycotoxins present in a given area during the sampling period. Deployment times, mostly in austral winter during the one-year sampling in $2014 / 2015$, were relatively variable due to bad weather conditions and poor accessibility of deployment sites to allow for quantitative comparisons among phycotoxin values of individual SPATT samplers. Nonetheless, the passive sampling clearly demonstrated that PTX was present in coastal waters of KGI all year round.

The presence of PTX-2 in turn is a strong indication for the presence of at least one of several PTX-producing species. To date, some Dinophysis species are the only known producers of PTX. There are several PTX variants reported in the literature (Sasaki et al. 1998; Miles et al. 2004), but PTX-2 dominates the PTX profiles of most species (Reguera et al. 2014, and references herein), which seems also to be true for PTX-producing Dinophysis in the KGI area. The same observation was made during the one-year SPATT sampling in 2014/2015, where PTX-2 was detected on all SPATT samplers. In contrast to the short SPATT samplings during the summer 2013 expedition where only PTX-2 was detected, on the SPATT samplers exposed for longer times (usually more than 4 weeks, each) during the 2014/2015 sampling period also pectenotoxin-2 seco acid (PTX-2sa) in addition to PTX-2 was detected. PTX-2sa is the hydrolysed form of PTX-2, in which the lactone moiety forming the macrocycle of the molecule is opened by hydrolysis and results in a linear structure (Fig. 7). The levels of PTX-2/ PTX-2sa in the Antarctic samples did not exceed $30 \mathrm{ng} \mathrm{g}^{-1}$ resin (Fig. 4, Table 3), which is one to two orders of magnitude below maximum values of PTX-2 found in areas with recurrent Dinophysis blooms such as in Southwest Ireland (220 $\mathrm{ng} \mathrm{g}^{-1}$ resin) (Fux et al. 2010) and in Northwest Spain (3000 $\mathrm{ng} \mathrm{g}^{-1}$ resin) (Pizarro et al. 2013). Even though SPATTs can only be regarded as semi-quantitative, these results clearly indicate a low abundance of PTX-producing species in coastal water of KGI.

PTX-2sa is hardly found in phytoplankton samples, but is a well-documented PTX-2 metabolite in mussels (Suzuki et al. 2001). The conversion of PTX-2 to PTX-2sa via hydrolysis is not only a result of metabolic shellfish activity, but also occurring spontaneously under high and low $\mathrm{pH}$. The fact that PTX-2sa was detected at higher proportions on SPATTs with longer exposure times may be an indication that hydrolysis of PTX-2 may also be catalyzed by the surface of the HP20 resin in addition to $\mathrm{pH}$ driven hydrolysis in the marine environment. In addition to PTX, one SPATT contained yessotoxin (YTX) known to be produced by gonyaulacoid dinoflagellate species Protoceratium reticulatum, Lingulodinium polyedra, Gonyaulax spinifera ( $\mathrm{Paz}$ et al. 2008) and G. taylorii (Álvarez et al. 2016). Although none of these species were detected in any of the phytoplankton samples analyzed by microscopy, $P$. reticulatum is a species known to occur and to be adapted to polar waters and is frequently found in the Arctic (Sala-Pérez et al. 2016). The absence of a producing species and the fact that there was only one positive SPATT sample for YTX is a weak indication for the presence of this phycotoxin. On the other hand, YTX has a relatively high detection limit and would hardly be detected at the concentrations that were found for PTX, which are detected more sensitively.

\section{Protistan plankton}

Using a molecular approach based on amplicon sequencing by NGS, a dominance of diatoms followed by dinoflagellates was detected in this study in Fildes Bay, KGI. There have been some reports of phytoplankton community 
Fig. 7 Chemical structures of a pectenotoxin-2 (PTX-2) and b pectenotoxin-2 seco acid (PTX-2sa)

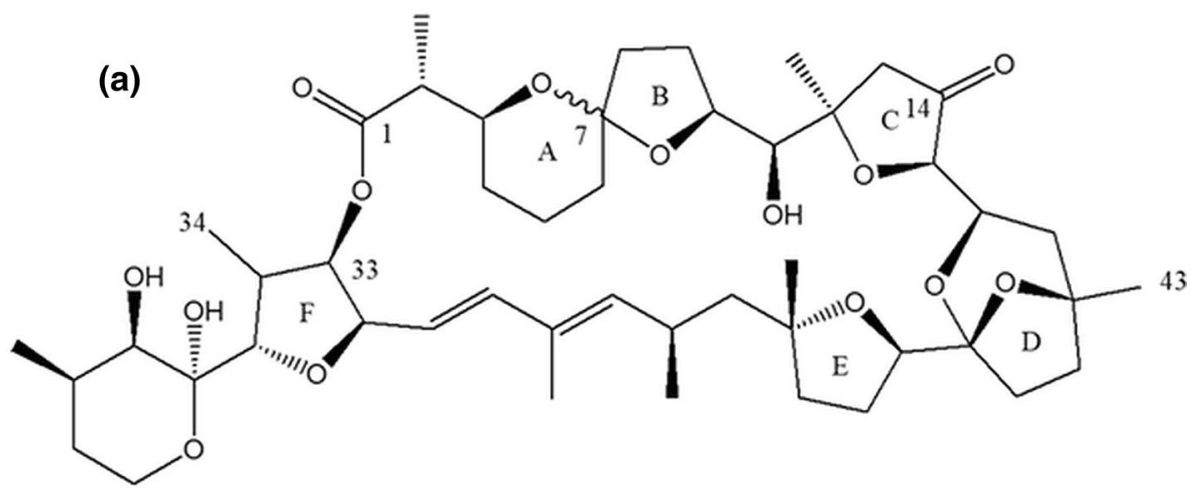

(b)
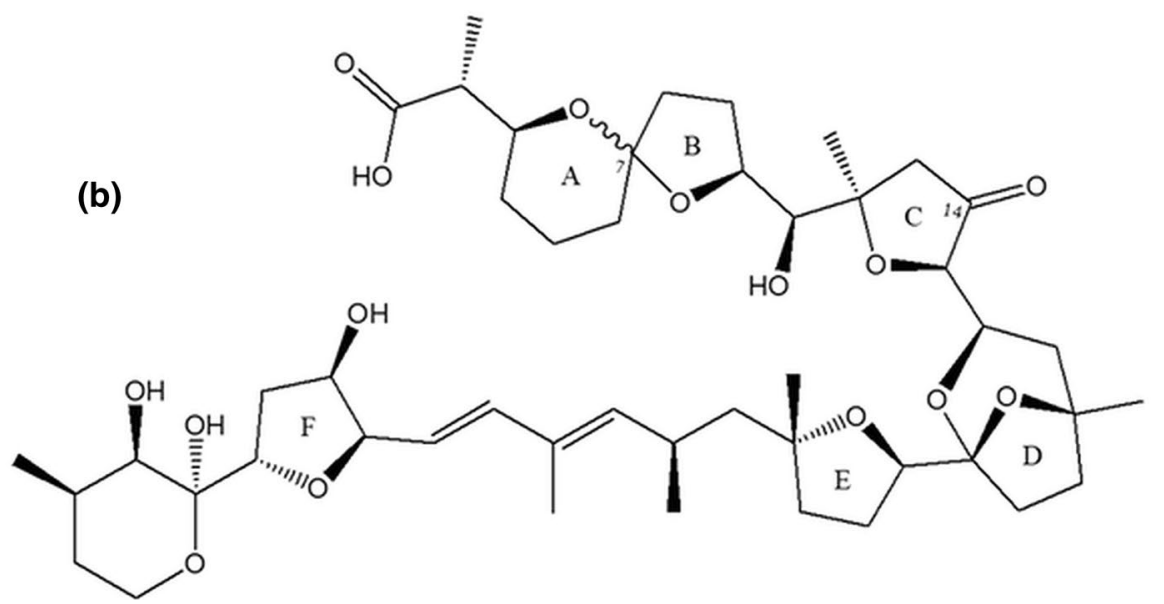

composition obtained using NGS in Antarctica (Luria et al. 2014; Wolf et al. 2015) and specifically in KGI (Luo et al. 2016; Moreno-Pino et al. 2016; Egas et al. 2017). Although it is known that NGS approaches for phytoplankton characterization have higher resolution than microscopy or pigments-based methods, especially in the case of small and inconspicuous protists, this approach depends on updated and curated databases that ensure that the annotation process of the sequences is accurate and precise. Yet, there are two important pitfalls for the application of this powerful tool in plankton and protist surveys. The first point is that the high variation of the $18 \mathrm{~S}$ rRNA copy number in marine protistan species, the taxonomic marker traditionally used, can vary from one to hundreds of thousands copies per cell (Zhu et al. 2005). The second point is that the selection of a genetic marker that is sufficiently resolute in terms of taxonomy, but at the same time general enough to allow the identification of the entire protistan plankton community is difficult. In this study, it was found that most of the sequences assigned to Dinophyceae were undetermined dinoflagellates, which suggest that the second element is particularly important here, combined with a general lack of polar planktonic protists in molecular databases.

Dinoflagellates found by microscopy in Potter Cove during summers $2010-2016$ were mainly dominated by small naked species, here collectively grouped as "gymnodinioids", as it usually occurs in other Antarctic areas (Nuccio et al. 2000; Korb et al. 2010). By contrast, no cells of Dinophysis were recorded during the examination of the 29 bottle samples, with a detection limit of 20 cells $\mathrm{L}^{-1}$. This is in accordance with the molecular data presented here, which showed a great abundance of dinoflagellates in the plankton community but that were not able to identify Dinophysis sp. within its members. Dinophysis species are usually observed at very low cell densities and therefore are seldom found by routine microscopic observations (Reguera et al. 2012). Moreover, Dinophysis cells are present at higher densities in thin layers, which usually require the use of depth-integrated hose samples to be detected (Escalera et al. 2012). Additional sampling efforts considering a higher temporal resolution and a more detailed depth-integrated sampling of the water column could contribute to the detection of Dinophysis species in the study area.

According to the compendium of Antarctic dinoflagellates by McMinn and Scott (2005), around 10 species of Dinophysis including species currently regarded as Phalacroma have been recorded in Antarctica. They mostly include insufficiently known species, such as Dinophysis antarctica, $D$. contracta, D. cornuta, D. meteori, D. operculoides, D. 
punctata, D. tenuivelata and D. tuberculata, which have been never associated with phycotoxin production. In contrast to the Southern Ocean, where nothing is known about phycotoxin-producing species, toxigenic Dinophysis species are known to occur from tropical to temperate and boreal waters (Reguera et al. 2012). Thus, the single finding of Dinophysis norvegica in a Niskin bottle sample from Fildes Bay suggests that toxigenic species of the genus Dinophysis could also be present in Antarctic waters. This confirms a previous record from the Bransfield Strait also based on microscopy data by Kuzmenko (2004). In addition, the distribution of $D$. norvegica has been recently extended to the southern southwestern Atlantic (Argentine Sea), where it was recorded at temperatures from 6 to $8.9^{\circ} \mathrm{C}$ (Fabro et al. 2016).

\section{Conclusion}

In this study, the first description of dissolved phycotoxins in Antarctic coastal waters gave indirect evidence of the presence of PTX-producing species and likely also YTX-producing species. This very low but recurrent detection of at least one phycotoxin in coastal waters of KGI, West Antarctic Peninsula indicates the potential risk of proliferation of $\mathrm{HAB}$ species in the Southern Ocean. Despite the finding of the presence of $\mathrm{HAB}$ species and their respective phycotoxins around KGI, there is a huge knowledge gap of the presence and geographic distribution of HAB species in other locations of the Southern Ocean and, certainly, a broader data base is needed for the development of a risk assessment of HAB events in Antarctica. Furthermore, phycotoxins can serve as sensitive chemotaxonomic markers for areas of very low HAB species abundances as they can be monitored by passive samplers, which is especially useful in remote areas with limited scientific infrastructure.

Electronic supplementary material The online version of this article (https://doi.org/10.1007/s00300-020-02628-z) contains supplementary material, which is available to authorized users.

Acknowledgements This work was partially financed by the Helmholtz-Gemeinschaft DeutscherForschungszentren through the research program PACES of the Alfred Wegener Institut-Helmholtz Zentrum für Polar- und Meeresforschung and by the European Commission under the 7th Framework Programme through the Action-IMCONet (FP7 IRSES, Action No. 319718), the International Cooperation Program (PCI) from CONICYT-FONDECYT through the Exchange Projects CONICYT-BMBF 2011 call (CONICYT Grant No. 2011-504/ BMBF Grant No. CHL 11/011 (01DN12102)), and by CONICYT-FONDECYT Grants Nos. 11121554 and 1190879. The authors thank Prof. Rodrigo de la Iglesia (Pontificia Universidad Católica de Chile) for providing the photograph of Dinophysis norvegica, Prof. Fang Peng (Great Wall Station) for SPATT deployment, the Instituto Antártico Chileno-INACH, the logistic personnel at Profesor Julio Escudero research station, the Instituto Antártico Argentino-Dirección Nacional del Antártico, the logistic and diving groups of Carlini Station for their technical assistance during the Antarctic expeditions and Annegret Müller, AWI for sample processing during the field campaign 2014 and toxin measurents.

Funding Open access funding enabled and organized by Projekt DEAL.

\section{Compliance with ethical standards}

Conflict of interest All authors declare that they have no conflicts of interest.

Open Access This article is licensed under a Creative Commons Attribution 4.0 International License, which permits use, sharing, adaptation, distribution and reproduction in any medium or format, as long as you give appropriate credit to the original author(s) and the source, provide a link to the Creative Commons licence, and indicate if changes were made. The images or other third party material in this article are included in the article's Creative Commons licence, unless indicated otherwise in a credit line to the material. If material is not included in the article's Creative Commons licence and your intended use is not permitted by statutory regulation or exceeds the permitted use, you will need to obtain permission directly from the copyright holder. To view a copy of this licence, visit http://creativecommons.org/licenses/by/4.0/.

\section{References}

Álvarez G, Uribe E, Regueiro J, Blanco J, Fraga S (2016) Gonyaulax taylorii, a new yessotoxins-producer dinoflagellate species from Chilean waters. Harmful Algae 58:8-15

Amaral-Zettler LA, McCliment EA, Ducklow HW, Huse SM (2009) A method for studying protistan diversity using massively parallel sequencing of V9 hypervariable regions of small-subunit ribosomal RNA genes. PLoS ONE 4(7):e6372

Anderson DM, Stock CA, Keafer BA, Nelson AB, Thompson B, McGillicuddy DJ, Keller M, Matrai PA, Martin J (2005) Alexandrium fundyense cyst dynamics in the Gulf of Maine. Deep-Sea Res II Top Stud Oceanogr 52:2522-2542

Armour KC, Marshall J, Scott JR, Donohoe A, Newsom ER (2016) Southern Ocean warming delayed by circumpolar upwelling and equatorward transport. Nat Geosci 9:549-554

Bailey SA (2015) An overview of thirty years of research on ballast water as a vector for aquatic invasive species to freshwater and marine. Aquat Ecosyst Health Manag 18:1-8. https://doi. org/10.1080/14634988.2015.1027129

Bresnan E, Hay S, Hughes SL, Fraser S, Rasmussen J, Webster L, Slesser G, Dunn J, Heath MR (2009) Seasonal and interannual variation in the phytoplankton community in the north east of Scotland. J Sea Res 61:17-25

Campana GL, Zacher K, Deregibus D, Momo FR, Wiencke C, Quartino ML (2018) Succession of Antarctic benthic algae (Potter Cove, South Shetland Islands): structural patterns and glacial impact over a four-year period. Polar Biol 41:377-396

Caporaso G, Lauber C, Walters W, Berg-Lyons D, Lozupone C, Turnbaugh PJ et al (2011) Global patterns of 16S rRNA diversity at a depth of millions of sequences per sample. PNAS 108(1):4516-4522

Ducklow HW, Fraser WR, Meredith MP, StammerjohnSE DSC, Martinson DG, Sailley SF, Schofield OM, Steinberg DK, Venables HJ, Amsler CD (2013) West Antarctic Peninsula: an ice-dependent coastal marine ecosystem in transition. Oceanography 26:190-203 
Egas C, Henríquez-Castillo C, Delherbe N, Molina E, Dos Santos AL, Lavin P, De La Iglesia R, Vaulot D, Trefault N (2017) Short timescale dynamics of phytoplankton in FildesBay, Antarctica. Antarct Sci 29:217-228. https://doi.org/10.1017/S0954102016000699

Escalera L, Pazos Y, Doval MD, Reguera B (2012) A comparison of integrated and discrete depth sampling for monitoring toxic species of Dinophysis. Mar Poll Bull 64:106-113

Fabro E, Almandoz GO, Ferrario ME, Tillmann U, Cembella AD, Krock B (2016) Distribution of Dinophysis species and their association with lipophilic phycotoxins in plankton from the Argentine Sea. Harmful Algae 59:31-41

Fraser CI, Kay GM, du Plessis M, Ryan PG (2017) Breaking down the barrier: dispersal across the Antarctic Polar Front. Ecography 40:235-237. https://doi.org/10.1111/ecog.02449

Fraser CI, Morrison AK, Hogg AM, Macaya EC, van Sebille E, Ryan PG, Padovan A, Jack C, Valdivia N, Waters JM (2018) Antarctica's ecological isolation will be broken by storm-driven dispersal and warming. Nat Clim Change 8:704-708

Fux E, Biré R, Hess P (2009) Comparative accumulation and composition of lipophilic marine biotoxins in passive samplers and in mussels (M. edulis) on the West Coast of Ireland. Harmful Algae 8:523-537

Fux E, Gonzalez-Gil S, Lunven M, Gentien P, Hess P (2010) Production of diarrhetic shellfish poisoning toxins and pectenotoxins at depths within and below the euphotic zone. Toxicon 56:1487-1496

García-Altares M, Casanova A, Bane V, Diogène J, Furey de la A, Iglesia P (2014) Confirmation of Pinnatoxins and Spirolides in Shellfish and Passive Samplers from Catalonia (Spain) by liquid chromatography coupled with triple quadrupole and high-resolution hybrid tandem mass spectrometry. Mar Drugs 12:3706-3732

Geyer WR, Scully ME, Ralston DK (2008) Quantifying vertical mixing in estuaries. Environ Fluid Mech 8:495-509. https://doi. org/10.1007/s10652-008-9107-2

Glibert P (2016) Margalef revisited: a new phytoplankton mandala incorporating twelve dimensions, including nutritional physiology. Harmful Algae 55:25-30

Gómez Izquierdo DR, Quartino ML, Morettini A et al (2014) Photographs of Potter Cove, King George Island, looking northeast towards glacier in 2014. Instituto AntárticoArgentino, Buenos Aires. https://doi.org/10.1594/PANGAEA.825233

Gómez Izquierdo DR, Quartino ML, Morettini A et al (2015) Photographs of Potter Cove, King George Island, looking northeast towards glacier in 2015. Instituto AntárticoArgentino, Buenos Aires. https://doi.org/10.1594/PANGAEA.841059

Gu H, Zeng N, Xie Z, Wang D, Wang W, Yang WD (2013) Morphology, phylogeny, and toxicity of Atama complex (Dinophyceae) from the Chukchi Sea. Pol Biol 36:427-436

Hallegraeff GM (2010) Ocean climate change, phytoplankton community responses, and harmful algal blooms: a formidable predictive challenge. J Phycol 46:220-235

Hallegraeff GM (2015) Transport of harmful marine microalgae via ship's ballast water: management and mitigation with special reference to the Arabian Gulf region. Aquat Ecosyst Health Manag 18:290-298

Hansen PJ, Ojamäe K, Berge T, Trampe ECL, Nielsen LT, Lips I, Kühl M (2016) Photoregulation in a kleptochloroplastidic dinoflagellate. Dinophysis acuta Frontiers Microbiol. https://doi. org/10.3389/fmicb.2016.00785

Harðardóttir S, Pančić M, Tammilehto A, Krock B, Møller E, Nielsen T, Lundholm N (2015) Dangerous relations in the arctic marine food web: interactions between toxin producing Pseudo-nitzschia diatoms and Calanus Copepodites. Mar Drugs 13:3809-3835

Henkel S, Kasten S, Hartmann JF, Silva-Busso A, Staubwasser M (2018) Iron cycling and stable Fe isotope fractionation in Antarctic shelf sediments, King George Island. Geochim Cosmochim Acta 237:320-338. https://doi.org/10.1016/j.gca.2018.06.042

Henley S, Schofield O, Hendry K, Schloss I, Steinberg D, Moffat C, Peck L, Costa D, Bakker DCE, Hughes C, Rozema P, Ducklow H, Abele D, Stefels J, van Leeuwe MA, Brussaard C, Buma AGJ, Kohut J, Sahade R, Friedlaender A, Venables H, Meredith M (2019) Variability and change in the west Antarctic Peninsula marine system: research priorities and opportunities. Progr Oceanogr 173:208-237

Hernando MP, Schloss IR, Malanga GF, Almandoz GO, Ferreyra GA, Aguiar MB, Puntarulo S (2015) Effects of salinity changes on coastal Antarctic phytoplankton physiology and assemblage composition. J Exp Mar Biol Ecol 466:110-119

Ho K-C, Kang S-H, Lam IHY, Hodgkiss IJ (2003) Distribution of Alexandrium tamarense in drake passage and the threat of harmful algal blooms in the Antarctic Ocean. Ocean Polar Res 25:625-631

Ho K-C, Lee TCH, Kwok OT, Lee FWF (2012) Phylogenetic analysis on a strain of Alexandrium tamarense collected from Antarctic Ocean. Harmful Algae 15:100-108

Höfer J, Giesecke R, Hopwood MJ, Carrera V, Alarcón E, González H (2019) The role of water column stability and wind mixing in the production/export dynamics of two bays in the Western Antarctic Peninsula. Prog Oceanogr 174:105-116

Hughes KA, Ashton GV (2016) Breaking the ice: the introduction of biofouling organisms to Antarctica on vessel hulls. Aquat Conserv-Mar Freshwater Ecosyst 27:158-164

Hughes KA, Convey P, Pertierra LR, Veg GC, Aragón P, OlallaTárraga MÁ (2019) Human-mediated dispersal of terrestrial species between Antarctic biogeographic regions: a preliminary risk assessment. J Environ Manag 232:73-79. https://doi. org/10.1016/j.jenvman.2018.10.095

John U, Litaker RW, Montresor M, Murray S, Brosnahan ML, Anderson DM (2014) Formal revision of the Alexandrium tamarense species complex (Dinophyceae) taxonomy: the introduction of five species with emphasis on molecular-based (rDNA) classification. Protist 165:779-804

Kim H, Ducklow HW, Abele D, Ruiz Barlett E, Buma AGJ, Meredith MP, Rozema PD, Schofield OM, Venables HJ, Schloss IR (2018) Inter-decadal variability of phytoplankton biomass along the coastal West Antarctic Peninsula. Philos Trans R Soc A 376:20170174. https://doi.org/10.1098/rsta.2017.0174

Korb RE, Whitehouse MJ, Gordon M, Ward P, Poulton AJ (2010) Summer microplankton community structure across the Scotia Sea: implications for biological carbon export. Biogeosciences 7:343-356

Kremp A, Anderson DM (2000) Factors regulating germination of resting cysts of the spring bloom dinoflagellate Scrippsiella hangoei from the northern Baltic Sea. J Plankton Res 22:1311-1327

Krock B, Seguel CG, Cembella AD (2007) Toxin profile of Alexandrium catenella from the Chilean coast as determined by liquid chromatography with fluorescence detection and liquid chromatography coupled with tandem mass spectrometry. Harmful Algae 6:734-744

Krock B, Tillmann U, John U, Cembella AD (2008) LC-MS-MS aboard ship: tandem mass spectrometry in the search for phycotoxins and novel toxigenic plankton from the North Sea. Anal Bioanal Chem 392:797-803

Kuzmenko LV (2004) Phytoplankton in the Western Bransfield Strait. Ukrainian Antarctic J 2:125-137 (in Russian)

Lefebvre KA, Quakenbush L, Frame E, Huntington KB, Sheffield G, Stimmelmayr R, Bryan A, Kendrick P, Ziel H, Goldstein T, Snyder JA, Gelatt T, Gulland F, Dickerson B, Gill V (2016) Prevalence of algal toxins in Alaskan marine mammals foraging in a changing arctic and subarctic environment. Harmful Algae $55: 13-24$ 
Li Z, Guo M, Yang S, Wang Q, Tan Z (2010) Investigation of pectenotoxin profiles in the yellow sea (China) using a passive sampling technique. Mar Drugs 8:1263-1272

Lindahl O, Lundve B, Johansen M (2007) Toxicity of Dinophysis spp. in relation to population density and environmental conditions on the Swedish west coast. Harmful Algae 6:218-231

Luo W, Li H, Gao S, Yu Y, Lin L, Zeng Y (2016) Molecular diversity of microbial eukaryotes in sea water from Fildes Peninsula, King George Island, Antarctica. Pol Biol 39:605-616. https://doi. org/10.1007/s00300-015-1815-8

Luria CM, Ducklow HW, Amaral-Zettler LA (2014) Marine bacterial, archaeal and eukaryotic diversity and community structure on the continental shelf of the western Antarctic Peninsula. Aquat Microb Ecol 73:107-121. https://doi.org/10.3354/ame01703

MacKenzie L, Beuzenberg V, Holland P, McNabb P, Selwood A (2004) Solid phase adsorption toxin tracking (SPATT): a new monitoring tool that simulates the biotoxin contamination of filter feeding bivalves. Toxicon 44:901-918

Mardones JI, Müller MN, Hallegraeff GM (2017) Toxic dinoflagellate blooms of Alexandrium catenella in Chilean fjords: a resilient winner from climate change. ICES J Mar Sci 74:988-995

Margalef R (1978) Life-forms of phytoplankton as survival alternatives in an unstable environment. Oceanol Acta 1:493-509

McMinn A, Scott FJ (2005) Dinoflagellates. In: Scott FJ, Marchant HJ (eds) Antarctic marine protists, Australian Biological Resources Study. AAD Hobart, Canberra, pp 202-250

Medlin LK, Lange M, Nöthig E-M (2000) Genetic diversity in the marine phytoplankton: a review and a consideration of Antarctic phytoplankton. Antarct Sci. https://doi.org/10.1017/s095410200 0000389

Mendes CRB, Tavano VM, Leal MC, de Souza MS, Brotas V, Garcia CAE (2013) Shifts in the dominance between diatoms and cryptophytes during three late summers in the Bransfield Strait (Antarctic Peninsula). Pol Biol 36:537-547

Miles CO, Wilkins AL, Samdal IA, Sandvik M, Petersen D, Quilliam MA, Naustvoll LJ, Rundberget T, Torgersen T, Hovgaard P, Jensen DJ, Cooney JM (2004) A novel pectenotoxin, PTX-12, in Dinophysis spp. and shellfish from Norway. Chem Res Toxicol 17:1423-1433

Moline MA, Claustre H, Frazer TK, Schofield O, Vernet M (2004) Alteration of the food web along the Antarctic Peninsula in response to a regional warming trend. Glob Change Biol 10:1973-1980

Moreno-Pino M, De la Iglesia R, Valdivia N, Henríquez-Castilo C, Galán A, Díez B, Trefault N (2016) Variation in coastal Antarctic microbial community composition at sub-mesoscale: Spatial distance or environmental filtering? FEMS Microbiol Ecol. https://doi.org/10.3354/ame0170310.1093/femsec/fiw088

Nuccio C, Innamorati M, Lazzara L, Mori G, Massi L (2000) Spatial and temporal distribution of phytoplankton assemblages in the Ross Sea. In: Faranda FM, Guglielmo L, Ianora A (eds) Ross sea ecology. Springer, Berlin, pp 231-245

Okolodkov YB (2005) The global distributional patterns of toxic, bloom dinoflagellates recorded from the Eurasian Arctic. Harmful Algae 4:351-369

Paz B, Daranas AH, Norte M, Riobó P, Franco JM, Fernández JJ (2008) Yessotoxins, a group of marine polyether toxins: an overview. Mar Drugs 6:73-102. https://doi.org/10.3390/md200 80005

Pizarro G, Moroño Á, Paz B, Franco J, Pazos Y, Reguera B (2013) Evaluation of passive samplers as a monitoring tool for early warning of dinophysis toxins in shellfish. Mar Drugs 11:3823-3845

Reguera B, Velo-Suárez L, Raine R, Gil Park M (2012) Harmful Dinophysis species: a review. Harmful Algae 14:87-106
Reguera B, Riobó P, Rodríguez F, Díaz PA, Pizarro G, Paz B, Franco JM, Blanco J (2014) Dinophysis toxins: causative organisms, distribution and fate in shellfish. Mar Drugs 12:394-461

Rodríguez-Marconi S, De la Iglesia R, Díez B, Fonseca CA, Hajdu E, Trefault N (2015) Characterization of bacterial, archaeal and eukaryote symbionts from antarctic sponges reveals a high diversity at a three-domain level and a particular signature for this ecosystem. PLoS ONE 10(9):e0138837. https://doi.org/10.1371/ journal.pone.0138837

Sala-Pérez M, Alpermann TJ, Krock B, Tillmann U (2016) Growth and bioactive secondary metabolites of arctic Protoceratium reticulatum (Dinophyceae). Harmful Algae 55:85-96

Sasaki K, Wright JLC, Yasumoto T (1998) Identification and characterization of pectenotoxin (PTX) 4 and PTX7 as spiroketal stereoisomers of two previously reported pectenotoxins. J Org Chem 63:2475-2480

Schloss IR, Ferreyra GA, Ruiz-Pino D (2002) Phytoplankton biomass in Antarctic shelf zones: a conceptual model based on Potter Cove, King George Island. J Mar Syst 36:129-143. https://doi. org/10.1016/S0924-7963(02)00183-5

Schloss PD, Westcott SL, Ryabin T, Hall JR, Hartmann M, Hollister EB (2009) Introducing mothur: open-source, platform-independent, community-supported software for describing and comparing microbial communities. Appl Environ Microbiol 75:7537-7541

Schloss IR, Abele D, Moreau S, Demers S, Bers AV, Gonzáalez O, Ferreyra GA (2012) Response of phytoplankton dynamics to 19-year (1991-2009) climate trends in Carlini Station (Antarctica). J Mar Syst 92:53-66

Schloss IR, Wasilowska A, Dumont D, Almandoz GO, Hernando MP, Michaud-Tremblay C-A, Saravia L, Rzepecki M, Monien P, Monien D, Kopczyńska EE, Bers AV, Ferreyra GA (2014) On the phytoplankton bloom in coastal waters of southern King George Island (Antarctica) in January 2010: an exceptional feature? Limnol Oceanogr 59:195-210

Shea D, Tester P, Cohen J, Kibler S, Varnam S (2006) Accumulation of brevetoxins by passive sampling devices. Afr J Mar Sci 28:379-381

Suzuki T, MacKenzie L, Stirling D, Adamson J (2001) Pectenotoxin-2 seco acid: a toxin converted from pectenotoxin-2 by the New Zealand Greenshell mussels, Perna canaliculatus. Toxicon 39:507-514

Tillmann U, Krock B, Alpermann TJ, Cembella AD (2016) Bioactive compounds of marine dinoflagellate isolates from western Greenland and their phylogenetic association within the genus Alexandrium. Harmful Algae 51:67-80

Turner J, Lu H, White I, King JC, Phillips T, Scott Hosking J, Bracegirdle TJ, Marshall GJ, Mulvaney R, Deb P (2016) Absence of 21st century warming on Antarctic Peninsula consistent with natural variability. Nature. https://doi.org/10.1038/nature18645

Utermöhl H (1958) Zur Vervollkommnung der quantitativen Phytoplanktonmethodik. Mitt Int Ver Theor Angew Limnol 9:1-38

Vernet M, Martinson DG, Iannuzzi RA, Stammerjohn S, Kozlowski W, Sines K, Smith R, Garibotti I (2008) Primary production within the sea-ice zone west of the Antarctic Peninsula: I-Sea ice, summer mixed layer, and irradiance. Deep Sea Res II 55:2068-2085

Vershinin A, Moruchkov A, Morton SL, Leighfield TA, Quilliam MA, Ramsdell JS (2006) Phytoplankton composition of the Kandalaksha Gulf, Russian White Sea: Dinophysis and lipophilic toxins in the blue mussel (Mytilus edulis). Harmful Algae 5:558-564

Wells ML, Trainer VL, Smayda TJ, Karlson BSO, Trick CG, Kudela RM, Ishikawa A, Bernard S, Wulff A, Anderson DM, Cochlan WP (2015) Harmful algal blooms and climate change: learning from the past and present to forecast the future. Harmful Algae 49:68-93. https://doi.org/10.1016/j.hal.2015.07.009

Wolf C, Kilias E, Metfies K (2015) Protists in the polar regions: comparing occurrence in the Arctic and Southern oceans 
using pyrosequencing. Polar Res. https://doi.org/10.3402/polar .v34.23225

Zhu F, Massana R, Not F, Marie D, Vaulot D (2005) Mapping of picoeucaryotes in marine ecosystems with quantitative PCR of the 18S rRNA gene. FEMS Microbiol Ecol 52:79-92. https://doi. org/10.1016/j.femsec.2004.10.006

Publisher's Note Springer Nature remains neutral with regard to jurisdictional claims in published maps and institutional affiliations. 